\title{
RELATIONSHIP AND DIGITAL COMPETENCIES OF INDIVIDUALS IN VALUE CREATION IN THE POLISH DIGITIZED ENVIRONMENT
}

\author{
Milena Ratajczak-Mrozek \\ Poznań University of Economics and Business, Poland \\ Marcin Wieczerzycki \\ Poznań University of Economics and Business, Poland \\ Aleksandra Hauke-Lopes \\ Poznań University of Economics and Business, Poland
}

\begin{abstract}
The aim of this paper is to indicate how the relational and digital competencies of individuals impact value creation processes during a cooperation between companies in a digitized environment. The paper applies the case study method and analyzes a digitized small company operating in Poland and its cooperators (confectionery shops, end commercial businesses and individual customers). The study contributes to the literature on individual and managerial competencies by addressing both the relational and digital competencies of individuals needed for value creation. It proposes a novel approach to the conceptualization of individuals' relational and digital competencies needed for value creation in a digitized environment by companies from both digital and traditional industries. It also presents managerial implications and identifies the individual relational and digital competencies of Polish managers that are needed to create value in a dynamic, digitized environment.
\end{abstract}

Keywords: value, digitalization, competencies, cooperation, Poland

DOI: http://dx.doi.org/10.15549/jeecar.v8i4.661

\section{INTRODUCTION}

Value, understood as key positive outcomes of companies' activities (Baraldi \& Lind, 2017; Haas et al., 2012), is recognized as a vital anchor of management action (Corsaro, 2019; Lindgreen et al., 2012). Value is not created solely by single and isolated companies, however (Vargo et al.,
2008). Therefore, the most recent studies underline that a vital role in value creation is played by relational capabilities (Rungsithong et al., 2017) or networking capabilities (Mu et al., 2017); that is, capabilities important in the improvement of cooperation and the management of business relationships (Mitrega et al., 2018), as well as in the creation of value. In 
current research, the capabilities or competencies needed to create value are mostly analyzed at the organizational level (Hsieh et al., 2012; Leite \& Bengtson, 2018; Smals \& Smits, 2011). It is important to note that, however, that "The company's activity is not limited to impersonal interactions between 'companies' or 'institutions'. Companies are managed by people" (Ratajczak-Mrozek, 2017, p. 4). Although Lepak, Smith \& Taylor (2007) stress that different levels of value creation analysis should be considered, including the individual, organizational and societal levels, still "Detailed investigations of individuals and their associated competencies relative to the company's operant and operand resources in value creation processes remains scant" (Waseem, Biggemann \& Garry, 2018, p. 6). Therefore, we are responding to the calls of Waseem et al. (2018) for further investigation into individuals and their competencies in the value creation process.

We focus specifically on the relational competencies of individuals, as these are single people who create and develop cooperation, and their competencies determine how this cooperation, including value creation, proceeds. Surprisingly, despite its importance, research into relational competencies at the individual level is limited (Corsaro, 2019; Kähkönen \& Lintukangas, 2018; Waseem et al., 2018).

The creation of value is, in part, determined by the business environment, which is undergoing a digital transformation (Garrido-Moreno et al., 2020; Ratten \& Jones, 2020). Digitalization impacts every area of companies' activities, both companies operating in a traditional, analogue way and those more technologically advanced. These changes affect cooperation between companies, as well as value creation. We can assume that in a digitized environment, both the relational and digital competencies of individuals (managers as well as employees) are important for value creation. Digital competencies are "the set of knowledge, skills, attitudes (...) that are required when using ICT and digital media" (Ferrari, 2013, p. 3). In the context of Poland, this can make value creation in the digitized environment doubly challenging, as not only do the relational competencies of Polish managers with regard to trust, openness and willingness to cooperate with others tend to be low, but the implementation of technologies based on cooperation also suffers in the process (Gracel \& Makowiec, 2017). Although there is some research on the level of digital competencies in Poland (Śledziewska et al., 2017; Żak, 2016), as well as studies in which digital competencies are crucial for business in general (Potemkin \& Rasskazova, 2020; Ravichandran, 2018), the problem of the individuals' competencies needed to create value resulting from cooperation in the context of Poland remains unexplored. Hence, the paper aims to indicate how the relational and digital competencies of individuals impact value creation processes during cooperation between companies in a digitized environment.

We apply the case study method and analyze a small, digitized company operating in Poland and its co-operators. The company is an online platform for confectionery shops, businesses and individual customers, providing online ordering of cakes. The case study method allows the problem to be investigated in depth by taking into account the dynamics of the specific context (Halinen \& Törnroos, 2005) and, as a result, analyze "how" the phenomena occur (Welch \& Paavilainen-Mäntymäki, 2014).

The contribution of our paper is twofold. First, we contribute to the literature on individual and managerial competencies, which despite their importance in value creation processes, remain unexplored. In particular, research combining relational and digital competencies in the context of value creation has been scarce and is usually focused on industries that rely heavily on technology such as mechanical and plant engineering (Kinkel et al., 2017). To fill the existing gap, we propose a novel approach to the conceptualization of individuals' relational and digital competencies needed for value creation in a digitized environment by companies from both digital and traditional industries. Second, we present managerial implications and identify the individual relational and digital competencies of Polish managers that are needed to create value in a dynamic, digitized environment. These competencies are important for managers working in industries considered as traditional but which, as a result of changes in the external environment, are forced to digitize some of the company's processes. 
Our paper is structured as follows. First, we discuss the concept of value creation and the literature on the competencies of individuals in cooperation and value creation, with a particular emphasis on relational and digital competencies in the context of Poland. Next, after a presentation of the methodology, we analyze the case study of a Polish online platform provider. Based on the analysis, we propose a framework for the relational and digital competencies needed by individuals to support value creation in a digitized environment. We conclude with the managerial implications of our findings.

\section{LITERATURE REVIEW}

The Importance of Individuals' Relational Competencies in Cooperation and Value Creation

Following Ford, Mattsson \& Snehota (2017, p. 30 ), we define value as a positive key outcome of "combining and recombining resources, coordinating activities and connecting individuals within and across businesses". Value is not created by a single company on its own, as resources or other forms of cooperation are needed to create value (Vargo et al., 2008). Therefore, the belief that as the result of cooperation value will be created, and that the created outcomes will outweigh any perceived sacrifices, is a necessary condition for the willingness to continue cooperation (Walter et al., 2001).

Of significant importance in the process of value creation are a company's internal capabilities, allowing different resources to be found, used and combined in order to respond to market competitors (Forkmann et al., 2018) or to manage cooperation with business partners (Möller \& Törrönen, 2003). In the context of cooperation, the importance of relational capabilities and/or networking capabilities for value creation has already been underlined (Kähkönen et al., 2015; Mu et al., 2017). These two types of capabilities (relational and networking), although discussed separately in the existing literature, amount to the same phenomenon; that is, the special organizational capabilities that are needed to cooperate with other business entities (Martin \& Bachrach, 2018; Mitrega et al., 2018). Relational capabilities are defined as the organizational capabilities needed to cooperate with other business entities, such as suppliers or customers (Chen \& Kitsis, 2017; Forkmann et al., 2018), and are strongly embedded in organizational routines (Ngugi, 2019). Networking capabilities, in turn, are understood as a company's ability to exploit existing relationships, as well as to establish new ones to achieve a competitive advantage (Mu et al., 2017). As these two types of capabilities refer to a similar phenomenon, from now on we will refer only to the former in the paper.

In the current literature, relational capabilities are mainly analyzed at the organizational level in the process of value creation. However, analysis of the capabilities important for value creation should also include the individual level (Lepak et al., 2007; Waseem et al., 2018). The rare exceptions that investigate the relational capabilities of an individual in the process of value creation are Kähkönen \& Lintukangas (2018), Waseem et al. (2018) and Corsaro (2019). These capabilities, relating specifically to individuals, are referred to as competencies. We adopt this terminology in our paper. This research shows that value creation depends on such individual relational competencies as a manager's ability to build trust and increase knowledge (Kähkönen \& Lintukangas, 2018), their ability to develop personal relationships, to communicate the value proposition and to engage in continuous dialogue (Corsaro, 2019). Waseem et al. (2018) propose a comprehensive conceptualization of the individual relational competencies important in value creation, which include in-role behaviors and extra-role behaviors. In-role behaviors include individuals' engagement in cooperation (in terms of interaction quality and relationship quality) and the understanding of performed activities (in terms of professional expertise and an actionoriented approach). Extra-role behavior embraces organizational citizenship behavior; that is, an individual's non-obligatory behavior that is frequently not recognized by a formal organizational reward system.

The Importance of Individuals' Digital Competencies in the Digitized Environment

The impact of the digitized environment is not limited to companies operating online or in the IT industry; since it changes how entire societies 
function, the digitized environment influences traditional (analogue) industries as well. For companies operating within a digitized environment, the digital competencies of their employees and managers are becoming of crucial importance (Ngoasong, 2018). These competencies are understood as "the set of knowledge, skills, attitudes [...] that are required when using ICT and digital media" in seven areas: information management, collaboration, communication and sharing, creation of content and knowledge, ethics and responsibility, evaluation and problem solving, and technical operations (Ferrari, 2013, p. 3). Therefore, some common themes between digital and relational competencies can be identified, particularly the focus on creating new knowledge and the ability to communicate and cooperate. That being said, this does not necessarily mean that possessing high relational competencies automatically equates to being equipped with high digital competencies or vice versa. Knowledge creation, communication, and the ability to cooperate in the case of digital competencies should be understood exclusively within the context of digital tools and technologies. It is, therefore, perfectly possible for an individual to possess the ability to communicate with others in an unmediated way, or by using traditional media such as a phone, while lacking the ability to effectively convey their thoughts and emotions via, for example, instant messaging. This inability to communicate using digital tools should not be confused with a general lack of technological skills - it can just as well be an effect of having no experience or a lack of embeddedness in a culture built around digital communication, which may occur despite having a general ability to use a given digital tool (Gunawardena, 1995; Potemkin \& Rasskazova, 2020). Conversely, individuals who experience problems with, for example, emotional management, and thus lack communication skills in face-to-face communication, may excel at communication via digital media (Myruski et al., 2020). Therefore, despite sharing the same name, communication, cooperation and knowledge creation competencies can mean different things depending on the context (relational or digital).

Despite the ongoing digital transformation, which sees companies operating in an increasingly digitized environment, the importance of digital competencies varies between industries, with traditional ones (such as agriculture or mining) usually less dependent on them, while in those more technologically involved (like IT and the financial industry) the demand for digital competencies is higher. That being said, the difference between traditional and technological industries seems to be diminishing with time, meaning that a basic set of technology-related skills becomes the standard expected from employees, regardless of the industry (Aletdinova et al., 2021) or the function of the employee within the company (Potemkin \& Rasskazova, 2020).

However, for value creation in the context of a digitized environment, employees must be (somewhat counterintuitively) equipped with both digital and non-digital competencies. To digitally transform business models properly, both digital and traditional processes need to be understood, and relational competencies like problem-solving and the ability to cooperate are required (Kinkel et al., 2017).

\section{Relational and Digital Competencies of Individuals in the Context of Poland}

When talking about the subject of relational and digital competencies within a digitized environment, it is important to consider the unique circumstances influencing this environment in the context of Poland. In Poland, digital competencies are generally low, particularly in comparison to other European countries (Gracel \& Makowiec, 2017; Żak, 2016), with only $44 \%$ of the population possessing basic digital skills, and only $46 \%$ basic software skills (European Commission, 2020). That said, under closer inspection, the situation proves to be much more nuanced. The digital competencies of Polish employees with higher education are similar to those of employees in other countries. Where the differences between Poland and other countries become evident is in the case of employees with primary and secondary education. This leads to a somewhat peculiar situation in which Polish companies do not usually encounter many problems with implementing advanced technological solutions (which are usually implemented by employees with higher education), but simultaneously encounter problems when trying to introduce 
relatively basic digital technologies, which do not require experts (Śledziewska et al., 2017).

Consequently, this leads to another problem.While Polish companies are generally aware of the importance of digital technologies (Adamik \& Nowicki, 2018), due to being unable to find employees equipped with basic digital competencies, they ultimately decide to not resign from incorporatethese technologies into their workflow. In turn, this diminishes the demand on the market for workers equipped with such competencies, reducing the pressure to develop them (Śledziewska et al., 2017). This cycle creates a barrier that prevents Polish companies from fully benefiting from the opportunities offered by the 4.0 industry. Some companies try to counteract this by hiring foreign employees; however, this introduces communication problems since Polish is hard to learn, and even if the new employee is fluent in English, the Polish employees might not be.

Similarly, relational competencies in Poland are also lacking, particularly in the case of managers who display low levels of trust, openness and a willingness to cooperate with others. This poses a challenge in implementing technologies based on cooperation and in utilizing solutions like cooperation platforms and competence centers (Gracel \& Makowiec, 2017), ultimately making the process of value creation more challenging.

All the factors mentioned above result in Poland constituting a unique context for the development of individual competencies concerning value creation.

\section{METHODOLOGY}

This paper applies a case study research method (Yin, 2009), which is advised for analysis aimed at understanding 'how' actions occur (Marschan-Piekkari \& Welch, 2004), and also matches the aim of our study. This type of research does not allow the application of statistical generalizations, a fact that constitutes its main limitation. To ensure analytic generalizability and construct validity (Healy \& Perry, 2000), we applied triangulation of methods during data collection (Woodside \& Baxter, 2013; Yin, 2009). We used transcripts of interviews and additional data from secondary sources, including internal documents, financial and sales reports from the company (hereafter referred to as Alpha), the company website and official materials published on the internet.

We base the analysis on the case study of a small digitized company operating in Poland and its business partners. The company operates as an online platform for confectionery shops, end businesses and individual customers, providing the online ordering of cakes. The analysis is based on in-depth interviews with key informants representing five companies (the online platform provider, three confectioneries that use the service and the IT supplier). This allows us to look at the problem of individuals' relational and digital competencies from different perspectives and additionally understand if there are differences between the digital competencies needed in IT and in traditional confectionery companies.

The data was collected during 13 interviews held between March 2020 and April 2021 (see Table 1 for details). Each interview lasted between 20 minutes and two hours. A special guide for the semi-structured interviews was developed, focusing on open-ended and probing questions to encourage discussion of the phenomena (Denzin \& Lincoln, 2012). The main questions included the impact of digitization ("Please describe if and how digital technologies affect the functioning of your company?"), the specificity of cooperation with a particular business entity ("Please describe what the cooperation with digital platform/IT supplier/confectionery $\mathrm{X}$ is like"), the value resulting from this cooperation ("How do you understand and where do you see the value of cooperation with digital platform/IT supplier/confectionery X"), and the important competencies of individuals ("What skills and competencies of yours or your employees were/are important when it comes to managing digital technology processes?" and "What skills and competencies of yours or your employees were/are important when it comes to cooperation with digital platform/confectionery X").

All the interviews were recorded and later transcribed. The data was analyzed using the constant comparative method, which helps to summarize the essence of the data and detect 
emerging themes (Thomas, 2011). As part of the analysis, we first looked for detailed information about the competencies of individuals important for cooperation, and those important for operating in a digitized environment. First, we based our analysis on the list of relational and digital competencies of individuals previously identified in the literature. In cases where no competencies mentioned in existing studies matched those identified in our findings, we named them ourselves, thus expanding on the existing literature. Second, we analyzed how the groups of competencies impacted the value creation process.

Table 1: Description of key informants and interviews conducted

\begin{tabular}{|c|l|l|l|}
\hline $\begin{array}{l}\text { Company } \\
\text { name }\end{array}$ & Type of company & Position of the respondent & $\begin{array}{l}\text { Duration of the } \\
\text { interview }\end{array}$ \\
\hline Alpha & Online platform provider & Co-owner 1 & $1) 90 \mathrm{~min}$ \\
& & & $\begin{array}{l}2) 110 \mathrm{~min} \\
3) 80 \mathrm{~min} \\
\end{array}$ \\
\cline { 3 - 4 } & & & $4) 78 \mathrm{~min}$ \\
\cline { 3 - 4 } & & Co-owner 2 & $1) 117 \mathrm{~min}$ \\
& & Network Development Manager & 2) $33 \mathrm{~min}$ \\
\cline { 3 - 4 } & & & $2) 26 \mathrm{~min}$ \\
\hline Beta & IT supplier & Co-owner & $30 \mathrm{~min}$ \\
\hline Zeta & B2B customer & Owner & $20 \mathrm{~min}$ \\
\hline Gamma & Confectionery 1 & Manager & $68 \mathrm{~min}$ \\
\hline Delta & Confectionery 2 & Co-owner & $43 \mathrm{~min}$ \\
\hline Epsilon & Confectionery 3 & Employee & \\
\hline
\end{tabular}

Source: author's work.

\section{FINDINGS AND DISCUSSION}

Table 2 presents, in summary form, the statements of the respondents that correspond to the identified relational and digital competencies which are important for cooperation in a digitized environment. In the last column of Table 2, we also present the specific value outcomes of co-creation for respective companies.

Table 2: Individuals' relational and digital competencies important for cooperation and value creation during cooperation

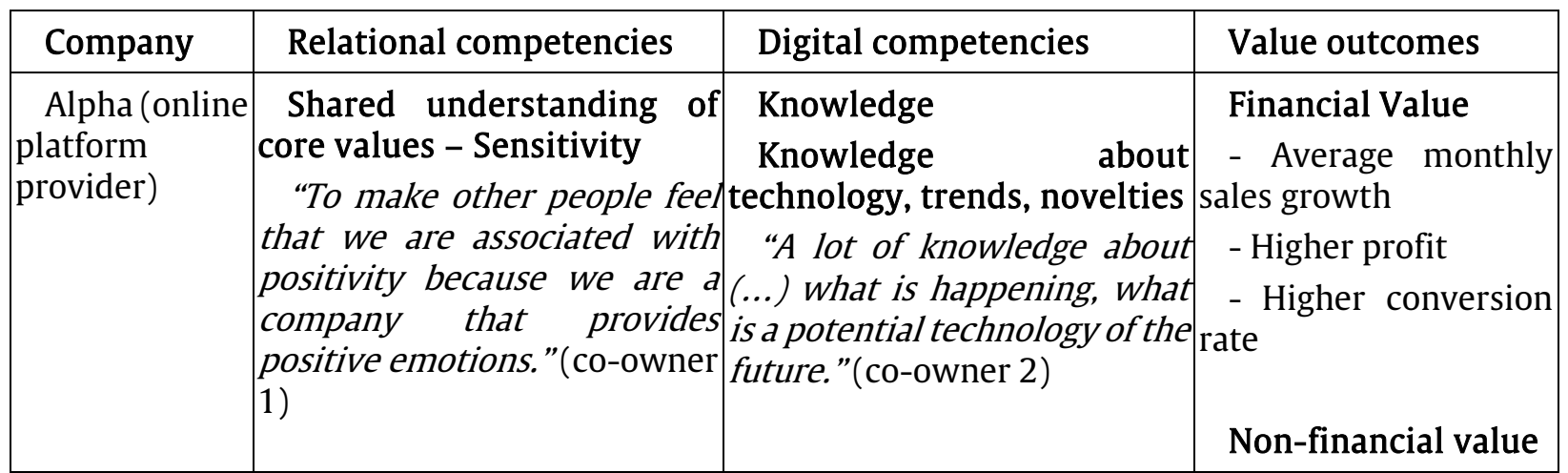




\begin{tabular}{|c|c|c|c|}
\hline & 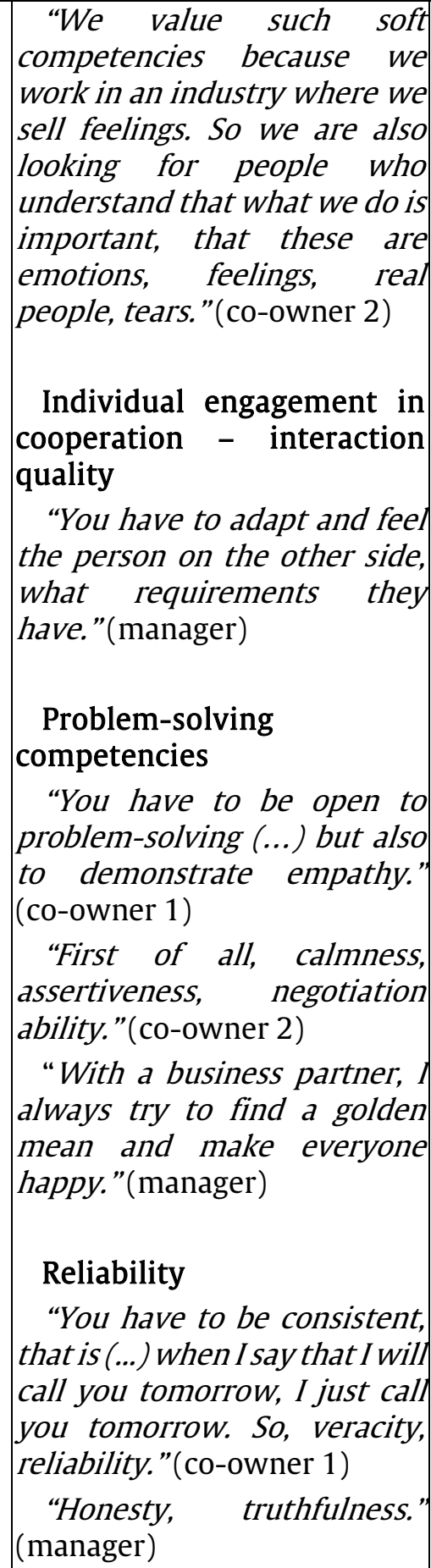 & 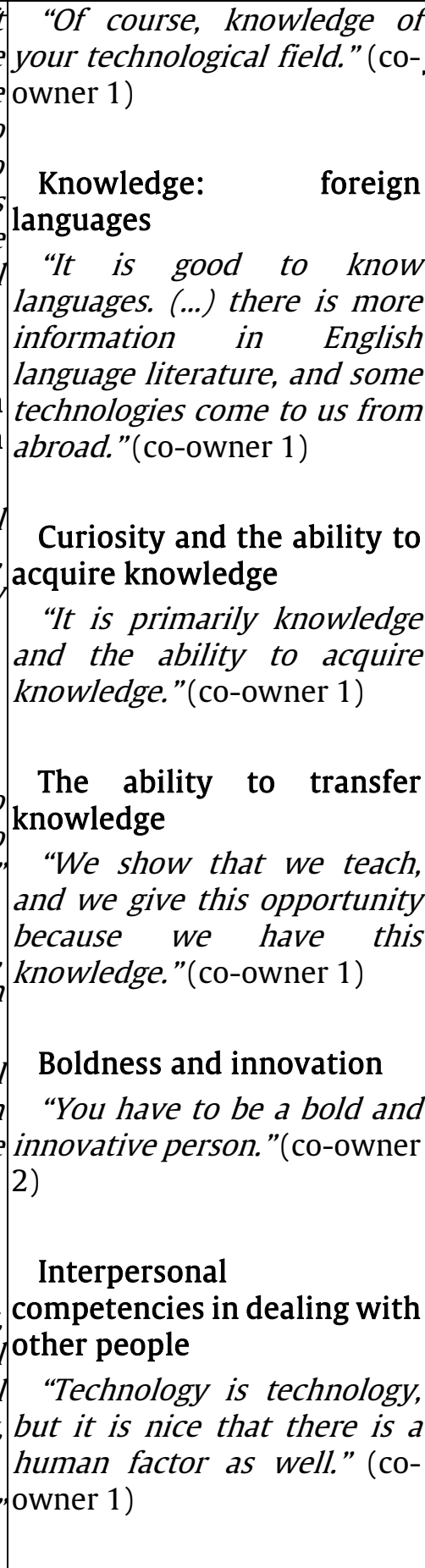 & $\begin{array}{l}\text { - Higher qual ity of } \\
\text { cooperation with } \\
\text { Tahphe ŻंContinitedsiness } \\
\text { partners } \\
\text { - Response to market } \\
\text { changes } \\
\text { - Improved offer } \\
\text { - Customer retention }\end{array}$ \\
\hline $\begin{array}{l}\text { Beta } \\
\text { (IT provider) }\end{array}$ & - & $\begin{array}{l}\text { Knowledge } \\
\text { Knowledge about } \\
\text { technology, trends, novelties } \\
\text { "It is important to recognize } \\
\text { new trends, particularly the } \\
\text { ones concerning user } \\
\text { experience." }\end{array}$ & $\begin{array}{l}\text { Financial value } \\
\text { - Higher turnover } \\
\text { - Recommendations } \\
\text { and gaining new } \\
\text { customers } \\
\text { Non-financial value }\end{array}$ \\
\hline
\end{tabular}




\begin{tabular}{|c|c|c|c|}
\hline & & $\begin{array}{l}\text { Curiosity and the ability to } \\
\text { acquire knowledge } \\
\text { "Constant development." }\end{array}$ & $\begin{array}{l}\text { Takesponsentinumarket } \\
\text { changes } \\
\text { - Market analysis } \\
\text { noticing new trends } \\
\text { - Higher trust among } \\
\text { cooperating companies }\end{array}$ \\
\hline $\begin{array}{l}\text { Delta } \\
\text { (confectionery) }\end{array}$ & $\begin{array}{l}\text { Individual engagement in } \\
\text { cooperation - interaction } \\
\text { quality } \\
\text { "In cases where the same } \\
\text { person has represented the } \\
\text { same company for a long time, } \\
\text { we learn to get along and from } \\
\text { that point the cooperation is } \\
\text { excellent." } \\
\text { Problem-solving } \\
\text { competencies } \\
\text { "We also try to help each } \\
\text { other. (...) We also try to find } \\
\text { some thread of understanding. } \\
\text { How to make both parties } \\
\text { satisfied." } \\
\text { Reliability } \\
\text { "I think it's sticking to these } \\
\text { arrangements. So, when we } \\
\text { (...) set something up, we stick } \\
\text { to the framework, standards." } \\
\text { Understanding } \\
\text { performed activities } \\
\text { professional expertise } \\
\text { "Product knowledge. (...) } \\
\text { This is the basis for us to know } \\
\text { what we are talking about." }\end{array}$ & $\begin{array}{l}\text { Technical operations } \\
\text { "Practically, basic computer } \\
\text { skills. Basic printer operation, } \\
\text { support for receiving e-mails." } \\
\text { Knowledge } \\
\text { Knowledge about } \\
\text { technology and process } \\
\text { handling from the customer's } \\
\text { perspective } \\
\text { "A lot of elderly people } \\
\text { ordered cakes over the } \\
\text { internet. (..) we had a lot of } \\
\text { calls where at some point the } \\
\text { caller simply got stuck and } \\
\text { didn't know where to click to } \\
\text { move on. So these basic } \\
\text { competencies in handling } \\
\text { orders from the perspective of } \\
\text { the client are also important." } \\
\text { Ability to acquire and } \\
\text { transfer knowledge } \\
\text { "Well, there is a lot of } \\
\text { knowledge that they [Alpha] } \\
\text { had and were able to pass on } \\
\text { to me so that we could create } \\
\text { this online store." }\end{array}$ & $\begin{array}{l}\text { Financial value } \\
\text { - Average monthly } \\
\text { sales growth } \\
\text { - Higher profit } \\
\text { - Higher conversion } \\
\text { rate } \\
\text { - Lower costs of } \\
\text { operations } \\
\text { Non-financial value } \\
\text { - Higher quality of } \\
\text { cooperation with } \\
\text { business partners } \\
\text { - Higher trust among } \\
\text { cooperating companies } \\
\text { - Understanding of } \\
\text { customers' needs } \\
\text { - Customer retention } \\
\text { - Streamlined } \\
\text { communication and } \\
\text { time-saving }\end{array}$ \\
\hline $\begin{array}{l}\text { Epsilon } \\
\text { (confectionery) }\end{array}$ & $\begin{array}{l}\text { Shared understanding of } \\
\text { core values - sensitivity } \\
\text { "It is the customer who has } \\
\text { to be satisfied because these } \\
\text { are their special days, } \\
\text { celebrations. This is when } \\
\text { families meet. Just like when } \\
\text { we have our family } \\
\text { celebrations. It is important } \\
\text { for us that it is nice." }\end{array}$ & 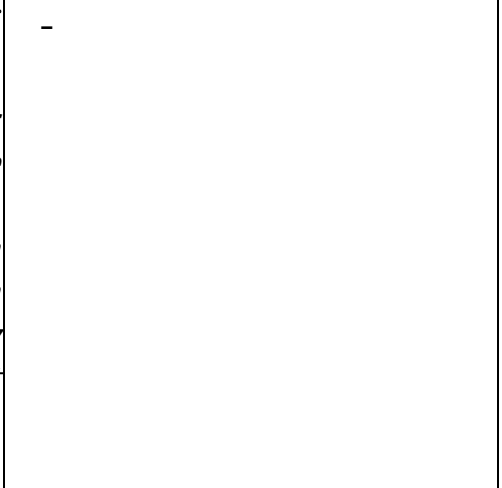 & $\begin{array}{l}\text { Financial value } \\
\text { - Lower costs of } \\
\text { operations } \\
\text { Non-financial value } \\
\text { - Higher quality of } \\
\text { cooperation with } \\
\text { business partners } \\
\text { - Higher trust among } \\
\text { cooperating companies }\end{array}$ \\
\hline
\end{tabular}




\begin{tabular}{|c|c|c|c|}
\hline & $\begin{array}{l}\text { Problem-solving } \\
\text { competencies } \\
\text { "There are no such problems } \\
\text { that we can't reach any } \\
\text { agreement on whatsoever, we } \\
\text { haven't had that yet." } \\
\text { Reliability } \\
\text { "Punctuality is important. } \\
\text { And reliability in these } \\
\text { deliveries." }\end{array}$ & & $\begin{array}{l}\text { Know-how on } \\
\text { stähten 2: Gontinuletonal } \\
\text { confectionery shop for } \\
\text { individual consumers } \\
\text { (company r had } \\
\text { experience only with } \\
\text { B2B customers) }\end{array}$ \\
\hline $\begin{array}{l}\text { Gamma } \\
\text { (confectionery) }\end{array}$ & $\begin{array}{l}\text { Individual engagement in } \\
\text { cooperation - interaction } \\
\text { quality } \\
\text { "Then there is contact with } \\
\text { Alpha to clarify these missing } \\
\text { details." }\end{array}$ & $\begin{array}{l}\text { Knowledge about } \\
\text { technology } \\
\text { "I believe that general } \\
\text { knowledge of the internet and } \\
\text { social media." }\end{array}$ & $\begin{array}{l}\text { Financial value } \\
\text { - Average monthly } \\
\text { sales growth } \\
\text { - Higher profit } \\
\text { - Higher conversion } \\
\text { rate } \\
\text { - Lower costs of } \\
\text { operations } \\
\text { Non-financial value } \\
\text { - Higher quality of } \\
\text { cooperation with } \\
\text { business partners } \\
\text { - Higher trust among } \\
\text { cooperating companies } \\
\text { - Customer retention } \\
\text { - Understanding of } \\
\text { customers buying } \\
\text { habits } \\
\text { - Streamlined } \\
\text { communication and } \\
\text { time-saving } \\
\text { - Know-how on } \\
\text { starting an e-shop }\end{array}$ \\
\hline
\end{tabular}

Source: author's work.

The analysis conducted shows a relatively high consistency among the traditional and IT-related companies analyzed in terms of the relational competencies of individuals needed to create value in a digitized environment. The first relational competency identified and confirmed by our results is the importance of individual engagement in cooperation - the interaction quality competence previously indicated by
Waseem et al. (2018). This shows that in the case of inter-organizational business relationships, the people responsible for contacts create an atmosphere of cooperation, which ultimately translates into the creation of value.

Second, our research shows a group of three interrelated relational competencies in individuals that are needed for smooth cooperation. These include (1) problem-solving 
competencies, (2) reliability and (3) understanding of the activities performed professional expertise. Although the problemsolving competence was underlined in research on, for example, cross-cultural business relationships (Andersen et al., 2009), or analyzed at the company level through the dynamic perspective (Winter, 2003), its importance has not until now been indicated in literature discussing relational competencies. This competence is of crucial importance in businesses using digital platforms where decisions have to be made swiftly. Employees possessing problem-solving competencies are able to handle conflicts, communicate with end consumers, find satisfactory solutions for both sides, and propose new ideas that result in smooth cooperation and value creation. Similarly, reliability, which we also identified as a competence important for value creation, has been omitted in the literature to date on value creation. This competence can be understood as "the quality of being able to be trusted or believed because of working or behaving well" (Cambridge Dictionary, 2021). Reliability can prevent conflicts in business relationships (Ratajczak-Mrozek et al., 2019), and thus facilitate problem-solving. Key informants underlined the importance of keeping to the terms of agreements and schedules in situations where the performed activities are dispersed among different companies (like the platform, confectionery shop and IT supplier). These two relational competencies, that is problem solving and reliability, are supported by an understanding of the activities performed professional expertise about the products on offer. This competence was indicated previously by Waseem et al (2018) and is especially relevant for companies from traditional industries, which in order to create value have to start using digital technologies in activities that had been previously performed entirely in a traditional way.

For a final relational competence of individuals important for value creation resulting from cooperation, our results point to the shared understanding of a core value, which in our case is sensitivity (the underlined statement by key informants: "we sell feelings"). Surprisingly, these competencies have also not been proposed in the literature to date. A core value reflects the core dimensions of operational activities and operational performance (Minerbo et al., 2021), which in our research means that the company does not merely sell cake; it sells feelings and emotions linked with a special occasion and the people for whom the cakes are bought. The creation of core value has been stressed, for example as a necessary requirement for the achievement of incremental innovation (Möller \& Törrönen, 2003). We point to a different aspect, however, which is the shared understanding of a core value by business partners as a prerequisite condition for value creation.

Based on the analysis, we can indicate four key digital competencies of individuals: (1) interpersonal competencies in dealing with other people, (2) boldness \& innovativeness, (3) knowledge, and (4) technical operations. The first is linked closely to what Ferrari (p.3) refers to as collaboration, defined as the ability to "link with others, participate in online networks \& communities, interact constructively". However, since our respondents highlighted the importance of the human factor in cooperation using digital tools, we decided to change the name to one that highlights this aspect properly, hence "interpersonal competencies in dealing with other people". This signifies a shift of focus towards the general ability to communicate and establish relationships using digital tools away from the Ferrari's more utilitarian approach, highlighting their application in the process of cooperation.

Conversely, the boldness \& innovativeness competence does not have a direct equivalent in the reviewed literature, though it does share some common ground with Ferrari's evaluation \& problem-solving, defined as an ability to "identify digital needs, solve problems through digital means, assess the information retrieved" (Ferrari, 2013, p.4). Boldness (understood as a tendency to take risks (Rogeri et al., 2020)) and innovativeness can potentially be used to solve problems, however, they can also be understood as a broader approach to business, going beyond problem-solving and manifesting themselves, for example, in a willingness to experiment. At the same time, problems can be solved without such an attitude.

The last two digital competencies of individuals identified in our study, knowledge 
and technical operations, match quite closely the terms utilized by Ferrari (2013). The former entails "knowledge [...] required when using ICT and digital media" (Ferrari, 2013, p.3). The author also mentions a specific area of digital competence, namely creation of content and knowledge, which entails the ability to "integrate and re-elaborate previous knowledge and content, construct new knowledge" (Ferrari, 2013, p.4). The respondents elaborated on specific areas of competencies in this category: aside from a general knowledge about technology and its developments, they also stressed the importance of the ability to acquire and transfer knowledge (both to other employees in the company and to customers). This matches the literature on the subject, which states that knowledge transfers are important, e.g. for cooperation and new product development (Mu et al., 2017). The respondents also stressed the importance of expertise in foreign languages, which fosters knowledge accumulation (since most sources are in English). Based on their responses, we understand knowledge competence in the digitized environment to be (1) knowledge of technology (2) the ability to acquire and transfer knowledge, and (3) foreign languages.

The fourth digital competence identified by the respondents matches what Ferrari (2013, p.4) refers to as technical operations, defined as the ability to "use technology and media to perform tasks through digital tools". For the respondents representing traditional industries (confectioneries), this competence mostly related to basic computer skills.

Cooperation and business relationships between companies within the digitized environment leads to value creation. After Ford et al. (2017), we assume a division of value into financial and non-financial outcomes of cooperation. The financial value outcomes indicated by key respondents include (1) improved financial results (coming from lower costs of operations, average monthly sales growth and higher profits, higher conversion rates) and (2) finding new business partners (due to e.g. recommendations from cooperating companies). In turn, non-financial value outcomes resulting from cooperation on digital platforms relate to value in terms of (1) spotting market trends (including a better response to market changes/trends, understanding of customer needs and buying habits as well as customer retention), (2) improved cooperation (higher quality of cooperation with business partners, including greater trust as well as timeefficiency) and (3) gained know-how on running a new business. Moreover, the two types of value outcomes (financial and non-financial) resulting from possessed digital and relational competencies are interrelated and influence each other. For example, improved offer or customer retention (non-financial value outcomes) creates financial value outcomes in terms of higher profit or monthly sales growth.

Based on our analysis, we propose in Figure $1 \mathrm{a}$ framework for the relational and digital competencies needed by individuals to support value creation in companies in a digitized environment.

So far, existing research dealing with the competencies of individuals needed for value creation resulting from companies' cooperation has focused on the importance of these competencies through the perspective of trust and knowledge (Kähkönen \& Lintukangas, 2018), or through the challenges of personal relationships in terms of value proposition (Corsaro, 2019). Our conceptualization of individuals' competencies indicates that to create value in the digitized environment, both relational and digital competencies are needed. What is important is that these competencies of individuals are closely interlinked. We may observe that individual engagement in cooperation (relational competence) is in some aspects similar to interpersonal competencies in dealing with other people (digital competence). Both types of competencies require developing personal relationships as well as attaching importance to relationship quality in order to create value, both financial and non-financial. The same similarity may be observed between problem-solving competencies and reliability on the one hand (relational competencies), and boldness \& innovativeness on the other (digital competence). The ability to take risks (boldness) allows problems to be solved more efficiently (Salvi \& Bowden, 2020). In some situations, in order to positively handle problems or conflicts, managers have to take risks and make difficult or 
brave decisions in order to reach the planned goals. Finally, understanding performed activities (relational competence) is linked with knowledge and technical operation within digital competencies.

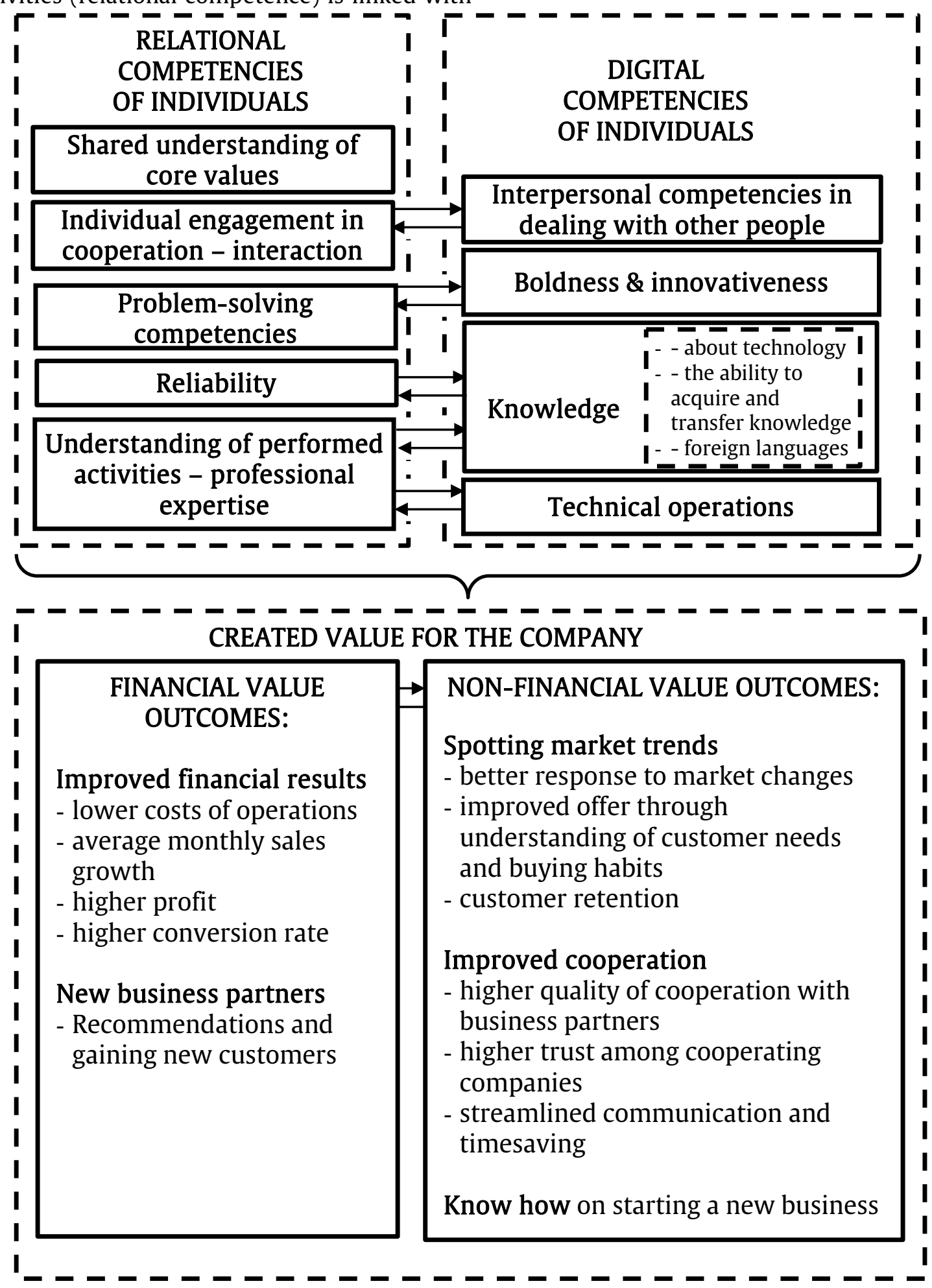

Figure 1: A conceptualization of individuals' relational and digital competencies required for value creation in a digitized environment.

Source: author's work. 
This underlines the importance of knowledge both at the traditional level (understanding of activities in the relationship) and at the digital level. Knowledge, and in particular the ability to apply it, is becoming the real competence of the future (Mu et al. 2017). This also means that while knowledge and interpersonal competencies are shared between relational and digital competencies, they are not the same, and an individual can possess one while lacking the other. Thus, our contribution lies not only in combining both types of competencies and showing that their coexistence is important for the creation of financial and non-financial value, but also in indicating that when operating in a digitized environment, solely digital competencies are not sufficient.

Our analysis also shows that technologies and the related digital competencies required differ depending on the industry. This is why Alpha (the online platform) and Beta (the IT provider) point to high requirements in terms of knowledge of technology, while the confectioneries, in contrast, consider requirements in this area as low, emphasizing the simplicity of the solutions utilized. Interestingly, despite the aforementioned observation that basic digital competencies are relatively low for non-expert workers (Śledziewska et al., 2017), none of the examined confectioneries had any trouble in adapting to Alpha's technological solutions, however, at the individual level, in one confectionery (Gamma), older employees had problems using the online platform. Therefore, as a solution, the company focused on employees' specialization - there are some employees responsible for online processes and others responsible for traditional production.

Moreover, our case shows how the technological and traditional worlds intermingle. The confectioneries emphasized that, while managing orders through the online platform is intuitive and requires only the most basic IT skills rather than expert competencies, these operations still have to be accompanied by complicated traditional processes (i.e., cake production), which require time and individual competencies of a different kind. This means that in order to create value, managers and employees in traditional industries (in our case confectioneries) need to utilize both types of competencies in tandem, for instance to explain the specificity of cake production (based on their understanding of performed activities relational competence) and using their interpersonal competencies in dealing with other people via digital media (digital competence).

Finally, based on the analysis we conducted, some more nuanced dependencies may be indicated between relational and digital competencies and particular value outcomes. Relational competencies, including shared understanding of core values, individual engagement in cooperation and reliability seem to be more important with regard to creating non-financial value embracing outcomes linked with: (1) spotting market trends (understanding customer needs and buying habits, response to market change, customer retention, improved offer), (2) improved cooperation (higher quality of cooperation with business partners, greater trust, streamlined communication and timesaving) and (3) know-how on starting a new business. Additionally, our results are in line with the findings of Waseem et al. (2018), who show that mutual reliance and the shared belief that a business relationship should develop are important in creating the non-financial value needed for further expansion.

The relational competencies of individuals, including an understanding of performed activities and professional expertise, are also important for financial value creation (such as higher profit or lower costs of operations). Through mutuality and adaptation of activities and resources, business partners are able to optimize their business activities since they know and adhere to the requirements, production cycle and market changes which allow them to obtain better financial results (Gadde et al., 2003).

In a digitized environment, managers also need to possess digital competencies in order to cooperate and create value. Interpersonal competencies in dealing with other people were found in our research to be important for nonfinancial value creation in terms of higher quality of cooperation with business partners and development of trust. As far as the other digital competencies are concerned, namely boldness \& 
innovativeness as well as technical operations, we found that they contribute mostly to financial value creation. More precisely, these two types of competencies not only allow the improvement of business operations in monetary terms but are also required for starting new businesses and expanding into new markets, which also translate into improved financial results.

\section{CONCLUSION}

Individuals' relational and digital competencies play an important role in value creation processes (Ferrari, 2013; Waseem et al., 2018). In the context of Poland, the key managerial takeaway is that individuals' relational and digital competencies have to be developed in parallel in order to create value in a digitized environment. Focusing exclusively on technological knowledge and skills will not be sufficient because to fully utilize many technologies, some degree of cooperation with others is required. Similarly, focusing on relational competencies while neglecting skills and knowledge in regard to digital technologies might limit the opportunities for cooperation. Even if these individuals offer traditional products, they have to constantly develop their knowledge about IT solutions, market trends and consumer preferences so as to respond to digital challenges and market changes.

Finding employees equipped with both digital and relational competencies in Poland, however, can be challenging, considering the fact that both on their own seem to be in short supply. Therefore, managers operating in the Polish market should instead focus on ensuring diversity of individuals' competencies in their companies. One way in which this could be achieved is through the inclusion of employees of different ages, as according to claims made by respondents, in general older employees are better equipped with relational competencies than their younger colleagues although they lack digital competencies, and vice versa. This could ensure that the company is not lacking in either of these areas, and could potentially lead to some transfer of competencies, particularly in regard to digital competencies. Another alternative would be to invest in specific training aimed at competence development. This could be particularly helpful for companies that lack digital competencies but cannot afford to hire new employees to compensate for this. Of course, the priorities in competence development should at least in part be determined by the industry in which a company operates. More traditional businesses, such as confectioneries, should focus on equipping their employees with only basic digital competencies, which will suffice for implementing digital technologies in their still predominantly traditional industry. For them, digital competencies can be considered secondary to relational competencies. Conversely, for IT companies it is the other way around - advanced digital competencies are required from the majority of employees, while relational competencies can be seen as secondary, although they may still be worth developing.

Our analysis is not free of certain limitations that simultaneously suggest directions for further research. Above all, our research is based on qualitative data and relates to the context of a specific country, Poland. It would be advisable to check to what extent the context of the country influences the relational and digital competencies needed to create value in the digitized environment. For this, quantitative research is needed. In addition, since our paper concerns a specific sector, an investigation of this interplay within the context of other industries could also prove valuable.

\section{ACKNOWLEDGEMENT}

The project financed within the Regional Excellence Initiative programme of the Minister of Science and Higher Education of Poland, years 2019-2022, grant no. 004/RID/2018/19, financing $3,000,000$.

\section{REFERENCES}

Adamik, A., \& Nowicki, M. (2018). Preparedness of companies for digital transformation and creating a competitive advantage in the age of Industry 4.0. Proceedings of the International Conference on Business Excellence, 12(1), 10-24. https://doi.org/10.2478/picbe-2018-0003

Aletdinova, A. A., Bakaev, M. A., \& Astapchuk, V. A. (2021). Intelligent analysis of digital economy competencies in agriculture labor. 
IOP Conference Series: Materials Science and Engineering, 1019(1). https://doi.org/10.1088/1757899X/1019/1/012046

Andersen, P. H., Christensen, P. R., \& Damgaard, T. (2009). Diverging expectations in buyerseller relationships: Institutional contexts and relationship norms. Industrial Marketing Management, 38(7), 814-824. https://doi.org/10.1016/j.indmarman.2008.0 4.016

Baraldi, E., \& Lind, J. (2017). Value Measuring and Value Appropriation in Business Networks. No Business Is an Island, 47-66. https://doi.org/10.1108/978-1-78714-549820171003

Chen, I. J., \& Kitsis, A. M. (2017). A research framework of sustainable supply chain management: The role of relational capabilities in driving performance. International Journal of Logistics Management, 28(4), 1454-1478. https://doi.org/10.1108/IJLM-11-2016-0265

Corsaro, D. (2019). Capturing the broader picture of value co-creation management. European Management Journal, 37(1), 99116. https://doi.org/10.1016/j.emj.2018.07.007

Denzin, N. K., \& Lincoln, Y. S. (2012). Strategies of qualitative inquiry (4th ed.). Sage.

European Commission. (2020). Digital Economy and Society Index (DESI) 2020. Human Capital.

Ferrari, A. (2013). Digital Competence in Practice: An Analysis of Frameworks. Joint Research Centre of the European Commission. https://doi.org/10.2791/82116

Ford, D., Mattsson, L.-G., \& Snehota, I. (2017). Management in the Interactive Business World. In No Business is an Island (pp. 2745). Emerald Publishing Limited. https://doi.org/10.1108/978-1-78714-549820171002

Ford, J. A., Verreynne, M.-L., \& Steen, J. (2017). Limits to networking capabilities: Relationship trade-offs and innovation. Industrial Marketing Management, 1-15. https://doi.org/10.1016/j.indmarman.2017.0 9.022
Forkmann, S., Henneberg, S. C., \& Mitrega, M. (2018). Capabilities in business relationships and networks: Research recommendations and directions. Industrial Marketing Management, 74(August), 4-26. https://doi.org/10.1016/j.indmarman.2018.0 7.007

Gadde, L. E., Huemer, L., \& Håkansson, H. (2003). Strategizing in industrial networks. Industrial Marketing Management, 32(5), 357-364. https://doi.org/10.1016/S00198501(03)00009-9

Garrido-Moreno, A., García-Morales, V., King, S., \& Lockett, N. (2020). Social Media use and value creation in the digital landscape: a dynamic-capabilities perspective. Journal of Service Management, 31(3). https://doi.org/10.1108/JOSM-09-20180286

Gracel, J., \& Makowiec, M. (2017). Kluczowe kompetencje menedżera $\mathrm{w}$ dobie czwartej rewolucji przemysłowej - przemysłu 4.0. Acta Universitatis Nicolai Copernici. Zarządzanie, 44(4), 105-129.

Gunawardena, C. N. (1995). Social Presence Theory and Implications for Interaction and Collaborative Learning in Computer Conferences. International Journal of Educational Telecommunications, 1(2), 147166.

Haas, A., Snehota, I., \& Corsaro, D. (2012). Creating value in business relationships : The role of sales. Industrial Marketing Management, 41(1), 94-105. https://doi.org/10.1016/j.indmarman.2011.1 1.004

Halinen, A., \& Törnroos, J. Å. (2005). Using case methods in the study of contemporary business networks. Journal of Business Research, 58(9 SPEC. ISS.), 1285-1297. https://doi.org/10.1016/j.jbusres.2004.02.00 1

Healy, M., \& Perry, C. (2000). Comprehensive criteria to judge validity and reliability of qualitative research within the realism paradigm. Qualitative Market Research: An International Journal, 3(3), 118-126. https://doi.org/10.1108/1352275001033386 1 
Hsieh, P.-F. F., Lee, C.-S. S., \& Ho, J. C. (2012). Strategy and process of value creation and appropriation in service clusters. Technovation, 32(7-8), 430-439. https://doi.org/10.1016/j.technovation.2011. 03.003

Kähkönen, A.-K., \& Lintukangas, K. (2018). Key dimensions of value creation ability of supply management. International Journal of Operations and Production Management, 38(4), 979-996.

https://doi.org/10.1108/IJOPM-04-20160189

Kähkönen, A.-K., Lintukangas, K., \& Hallikas, J. (2015). Buyer's dependence in value creating supplier relationship. Supply Chain Management, 20(2), 151-162. https://doi.org/10.1108/SCM-02-2014-0062

Kinkel, S., Schemmann, B., \& Lichtner, R. (2017). Critical Competencies for the Innovativeness of Value Creation Champions: Identifying Challenges and Work-integrated Solutions. Procedia Manufacturing, 9. https://doi.org/10.1016/j.promfg.2017.04.02 1

Leite, E., \& Bengtson, A. (2018). A business network view on value creation and capture in public-private cooperation. Industrial Marketing Management, 73, 181-192. https://doi.org/10.1016/j.indmarman.2018.0 2.010

Lepak, D. P., Smith, K. G., \& Taylor, M. S. (2007). Introduction to Special Topic Forum: Value Creation and Value Capture: A Multilevel Perspective. The Academy of Management Review, 32(1), 180-194.

Lindgreen, A., Hingley, M. K., Grant, D. B., \& Morgan, R. E. (2012). Value in business and industrial marketing: Past, present, and future. Industrial Marketing Management, 41(1), 207-214.

https://doi.org/10.1016/j.indmarman.2011.1 1.025

Marschan-Piekkari, R., \& Welch, C. (2004). Qualitative Research Methods in International Business: The State of the Art. In R. Marschan-Piekkari \& C. Welch (Eds.), Handbook of Qualitative Research Methods for International Business (pp. 5-24). Edward Elgar.
Martin, J. A., \& Bachrach, D. G. (2018). A relational perspective of the microfoundations of dynamic managerial capabilities and transactive memory systems. Industrial Marketing Management, 74, 27-38. https://doi.org/10.1016/j.indmarman.2018.0 7.008

Minerbo, C., Kleinaltenkamp, M., \& Artur Ledur Brito, L. (2021). Unpacking value creation and capture in B2B relationships. Industrial Marketing Management, 92, 163-177. https://doi.org/10.1016/j.indmarman.2020.1 1.011

Mitrega, M., Henneberg, S. C., \& Forkmann, S. (2018). Capabilities in business relationships and networks: An introduction to the special issue. Industrial Marketing Management, 74(August), 1-3. https://doi.org/10.1016/j.indmarman.2018.0 7.006

Möller, K. E. K., \& Törrönen, P. (2003). Business suppliers ' value creation potential A capability-based analysis. Industrial Marketing Management, 32(2), 109-118. https://doi.org/10.1016/S00198501(02)00225-0

Mu, J., Thomas, E., Peng, G., \& Di Benedetto, A. (2017). Strategic orientation and new product development performance: The role of networking capability and networking ability. Industrial Marketing Management, 64, 187-201.

https://doi.org/10.1016/j.indmarman.2016.0 9.007

Myruski, S., Quintero, J. M., Denefrio, S., \& Dennis-Tiwary, T. A. (2020). Through a Screen Darkly: Use of Computer-Mediated Communication Predicts Emotional Functioning. Psychological Reports, 123(6). https://doi.org/10.1177/0033294119859779

Ngoasong, M. Z. (2018). Digital entrepreneurship in a resource-scarce context: A focus on entrepreneurial digital competencies. Journal of Small Business and Enterprise Development, 25(3). https://doi.org/10.1108/JSBED-01-20170014

Ngugi, I. K. (2019). Co-creating Value in the Dyadic Relationships of Small and Large 
Firms in the Agri-food Sector. Journal of International Food \& Agribusiness Marketing, 31(1), 52-68. https://doi.org/10.1080/08974438.2018.147 1638

Potemkin, V., \& Rasskazova, O. (2020). Digital competence of employees and the value of human resources in the development strategy of enterprises. IOP Conference Series: Materials Science and Engineering, 940(1). https://doi.org/10.1088/1757899X/940/1/012098

Ratajczak-Mrozek, M., Fonfara, K., \& HaukeLopes, A. (2019). Conflict handling in small firms' foreign business relationships. Journal of Business and Industrial Marketing, 34(1). https://doi.org/10.1108/JBIM-10-2018-0316

Ratajczak-Mrozek, Milena. (2017). Network Embeddedness. Examining the Effect on Business Performance and Internationalization. Palgrave Macmillan. https://doi.org/10.1007/978-3-319-56511-8

Ratten, V., \& Jones, P. (2020). New challenges in sport entrepreneurship for value creation. International Entrepreneurship and Management Journal, 16(3). https://doi.org/10.1007/s11365-020-00664$\mathrm{Z}$

Ravichandran, T. (2018). Exploring the relationships between IT competence, innovation capacity and organizational agility. Journal of Strategic Information Systems, 27(1). https://doi.org/10.1016/j.jsis.2017.07.002

Rogeri, N., Meireles, M., Sanches, C., Ferreira, S., \& Marietto, M. L. (2020). Proposal of artifact to measure degree of boldness in business social actors. Brazilian Administration Review, 17(1), 1-23. https://doi.org/10.1590/18077692bar2020190033

Rungsithong, R., Meyer, K. E., \& Roath, A. S. (2017). Relational capabilities in Thai buyersupplier relationships. Journal of Business and Industrial Marketing, 32(8), 1228-1244. https://doi.org/10.1108/JBIM-02-2017-0027

Salvi, C., \& Bowden, E. (2020). The relation between state and trait risk taking and problem-solving. Psychological Research, 84(5), 1235-1248. https://doi.org/10.1007/s00426-019-01152$\mathrm{y}$

Śledziewska, K., Gabryelczyk, R., \& Włoch, R. (2017). The Gap in the Digital Competence : The Diagnosis for Poland. Roczniki Kolegium Analiz Ekonomicznych / Szkoła Główna Handlowa, 45, 159-175.

Smals, R. G. M., \& Smits, A. A. J. (2011). Value for value-The dynamics of supplier value in collaborative new product development. https://doi.org/10.1016/j.indmarman.2011.1 1.022

Thomas, G. (2011). How to do Your Case Study. A guide for students \& researchers. Sage.

Vargo, S. L., Maglio, P. P., \& Akaka, M. A. (2008). On value and value co-creation: A service systems and service logic perspective. European Management Journal, 26, 145152. https://doi.org/10.1016/j.emj.2008.04.003

Walter, A., Ritter, T., \& Gemünden, H. G. (2001). Value Creation in Buyer-Seller Relationships Theoretical Considerations and Empirical Results from a Supplier's Perspective. Industrial Marketing Managemen, 30(4), 365-377. https://doi.org/https://doi.org/10.1016/S001 9-8501(01)00156-0

Waseem, D., Biggemann, S., \& Garry, T. (2018). Value co-creation: The role of actor competence. Industrial Marketing Management, 70, 5-12.

https://doi.org/10.1016/j.indmarman.2017.0 7.005

Welch, C., \& Paavilainen-Mäntymäki, E. (2014). Putting Process (Back) In: Research on the Internationalization Process of the Firm. International Journal of Management Reviews, 16(1), 2-23. https://doi.org/10.1111/ijmr.12006

Winter, S. G. (2003). Understanding Dynamic Capabilities. Strategic Management Journal, 24(10). https://doi.org/10.1002/smj.318

Woodside, A. G., \& Baxter, R. (2013). Achieving accuracy, generalization-to-contexts, and complexity in theories of business-tobusiness decision processes. Industrial Marketing Management, 42(3), 382-393. https://doi.org/10.1016/j.indmarman.2013.0 2.004 
Yin, R. K. (2009). Case Study Research: Design and methods (4th ed.). Sage.

Żak, K. (2016). The evaluation of the digital competences of Poland and Polish enterprises in the concept of the multicriteria measurement of digitization. Ekonomiczne Problemy Usług, 123, 109117.

https://doi.org/10.18276/epu.2016.123-11

\section{ABOUT THE AUTHORS}

Milena Ratajczak-Mrozek, email: milena.ratajczak-mrozek@ue.poznan.pl

Dr. Milena Ratajczak-Mrozek is an Associate Professor in the Department of International Marketing at Poznań University of Economics and Business, Poland. Her main areas of research include companies' relationships and cooperation in an international setting as well as performance in the global market. She has published in Industrial Marketing Management, Journal of Business Research, Creativity Innovation Management and Journal of Business \& Industrial Marketing. She is the board Member of the Industrial Marketing and Purchasing Group, international network of scholars who approach marketing, technological development, and management from an interactive perspective.

Dr. Marcin Wieczerzycki is an Assistant Professor in the Department of International Marketing at Poznań University of Economics and Business, Poland. His research interests include consumer behavior and value cocreation in the technological context of new media.

Dr. Aleksandra Hauke-Lopes is an Assistant Professor in the Department of International Marketing at Poznań University of Economics and Business, Poland. Her scientific research focuses on value creation in business networks as well as international marketing and cooperation on business-to-business markets. She has published in Journal of Business \& Industrial Marketing. 